\title{
KOMITMEN KARYAWAN DITINJAU DARI \\ KUALITAS HUBUNGAN ATASAN-BAWAHAN \\ DAN PERSEPSI TERHADAP PENGEMBANGAN KARIR
}

\author{
Ika Candra \\ Asmadi Alsa \\ Universitas Gadjah Mada
}

INTISARI

Tujuan penelitian ini jalah untuk mengetahui adafidaknya korelasi antara kualitas hubungan atasan-bawahan dan persepsi terhadap pengembangan karir dengan komitmen karyawan pada perusahaan. Asumsi teonitiknya adalah semakin berkualitas hubungan atasan-bawahan dan semakin positif persepsi karyawan ter hadap pengembangan karir, maka komilmen karyawan pada perusahaan semakin tinggi.

Subjek penelitian adalah karyawan tetap PT Intan Pariwara, Klaten, yang diambil secara acak sebanyak 107 karyawan dari populasinya, yang memiliki ciri-ciri: masa kerja lebih satu tahun dan pendidikan minimal adalah SLTA Melalui metode analisis regresi dua prediktor diketahui bahwa terdapat korelasi yang sangat signifikan antara variabel kualitas hubungan atasan-bawahan dan variabel persepsi karyawan terhadap pengembangan karir dengan komitmen karyawan pada perusahaan. Secara sendiri-sendiri dikelahui bahwa terdapat korelasi positif yang sangat signifikan baik antara variabel kualitas hubungan atasan-bawahan dengan komitmen karyawan pada perusahaan, maupun antara persepsi karyawan terhadap perkembangan karir dengan komitmen karyawan pada perusahaan.

Kata kuncl : komitmen, kategori sikap, kategori perilaku, kualitas hubungan, persepsi terhadap pengembangan karir, dyad.

\section{Ika Candra adalah alumnus Fakultas Psikologi UGM.}

Asmadi Alsa, lahir of Pagaralam (Sumatera Selatan) 10 September 1947, adalah dosen Fakultas Psikologi UGM Yogyakata Pernah menjabat sebagai Pembantu Dekan I (1985-1988) dan ketua bagian Psikologi Pendidikan dan Psikometri di Fakultas Psikologi UGM (1988-1991). Jabatan organisasi saat ini ialah Sekretanis Keluarga Alumni HMI (KAHMI) Wilayah Propinsi DIY.

\section{PENGANTAR}

alam menghadapi era liberalisasi perdagangan, ada dua pendapat yang saling bertentangan di Indonesia. Di satu pihak sebagian pakar ekonomi dengan optimis menyatakan bahwa dunia usaha Indonesia akan mampu bersaing di pasar global, sebagai konsekuensi logis dari terbukanya pasar. Di pihak lain, para pakar ekonomi lainnya menyatakan pesimis akan kemampuan dunia usaha Indonesia untuk bersaing. Terlepas dari mampu atau tidak 
mampu dalam persaingan, mau tidak mau para pengusaha Indonesia harus menghadapinya karena Indonesia telah ikut meratifikasi perjanjian GATT, APEC, dan AFTA (Nasution, 1994).

Sesuai dengan kesepakatan liberalisasi perdagangan tersebut, maka pada saat sekarang ini perusahaan-perusahaan di Indonesia harus mempersiapkan diri sebaik-baiknya untuk menghadapi perusahaan-perusahaan asing yang akan dijinkan beroperasi di Indonesia kelak. Perusahaanperusahaan yang siap, baik kualitas sumber daya manusia, manajemen, teknologi, dan strategi, akan mampu bersaing dengan perusahaan-perusahaan asing tersebut, sedangkan perusahaan-perusahaan yang tidak siap diduga akan tersingkir dari ketatnya persaingan yang dihadapi, baik di pasar domestik maupun pasar giobal.

Selama ini banyak perusahaan dalam dunia perindustrian yang menerapkan strategi meraih kesuksesan dan keunggulan bersaing berdasarkan landasan sukses yang selalu berubah, seperti teknologi produk dan proses, pasar yang diproteksi dan deregulasi, akses ke sumber daya keuangan dan skala ekonomis. Pada masa sekarang strategi bersaing semacam in: masih merupakan sumber-sumber kesuksesan untuk bersaing bagi suatu perusahaan, namun keampuhannya telah berkurang dibandingkan dengan masa lalu dan bukan merupakan sumber-sumber kesuksesan bersaing yang lestari (Preffer, 1996).

\section{TENAGA KERJA BERKOMITMEN TINGGI}

Di indonesia banyak perusahaan dapat memperoleh kesuksesan karena adanya praktek monopoli. Selain itu kesuksesan juga dapat dicapai karena adanya proteksi dan subsidi, terutama industri-industri yang dianggap memiliki posisi kunci dan stra- tegis. Praktik semacam ini tentunya akan hilang pada era liberalisasi perdagangan nanti. Oleh sebab itu mau tidak mau perusahaan harus mengubah landasan suksesnya agar dapat mencapai keunggulan dalam persaingan bebas yang ketat. Dikatakan oleh Pfeffer (1996) bahwa pada masa sekarang ini hanya ada satu landasan sukses untuk keunggulan bersaing yang lestari bagi perusahaan, yaitu bagaimana mengelola faktor sumber daya manusia di perusahaan. Perusahaan yang berusaha mencapai keunggulan bersaingnya menggunakan strategl melalui sumber daya manusia, menunjukkan bahwa dengan tenaga kerja yang berkomitmen tinggi suatu perusahaan suatu perusahaan akan marnpu mengungguli perusahaan-perusahaan yang menggunakan strategi bersaing yang lain secara berulang-uiang.

Pentingnya komitmen yang tinggi pada karyawan bagi suatu perusahaan, dikemukakan oleh Mathieu dan Zajac (1990). yang menyatakan bahwa dengan adanya komitmen tinggi pada karyawan, perusahaan akan mendapatkan dampak positif. seperti meningkatnya produktivitas, kualitas kerja. dan kepuasan kerja, serta menurunnya tingkat keterlambatan, absensi, dan turnover.

Semua dampak positif yang diperoleh sebagai konsekuensi dari para karyawan yang memiliki komitmen tinggi terhadap organisasi kerja tentu saja sangat berguna bagi perusahaan. Oleh karena itu, strategi mencapai keunggulan bersaing melalui manusia itu cukup realistis untuk diterapkan perusahaan-perusahaan di indonesia (P'elfer, 1996).

Pada masa sekarang, masih banyak perusahaan di indonesia yang memiliki karyawan yang berkomitmen rendah. Seperti yang diberitakan oleh Harian Kompas (1995), sekitar 400 karyawan Hotel Kartika Plaza Jakarta melakukan aksi mogok, yang 
akibatnya berbuntut pada pemutusan hubungan kerja. Harian Kompas (1996) edisi berbeda memberitakan tentang aksi perusakan kantor dan aset perusahaan yang dilakukan oleh sekitar 1000 buruh pabrik tekstil PT Frans Brother Sejati di Tangerang. Contoh lain yang menunjukkan komitmen karyawan belum tinggi adalah sebanyak 15 bankir profesional dari Citibank pindah ke Bank Papan Sejahtera (Harian Bernas, 1996).

Dengan tenaga kerja yang berkomitmen rendah, banyak perusahaan of indonesia akan sulit bersaing pada era liberalisasi perdagangan nanti. Karena itu perusahaan-perusahaan tersebut harus mampu membina tenaga kerja yang berkomitmen tinggi. Untuk membina tenaga kerja yang berkomitmen tinggi harus diketahui apa yang dimaksud dengan komitmen dan faktor apa saja yang berperan dalam pembentukan komitmen.

Menurut Steers dan Porter (1983), pengertian Komitmen terhadap perusahaan dapat dibedakan menjadi dua, yaitu pengertian komitmen dalam kategori sikap dan pengertian komitmen dalam kategori perilaku. Ditinjau dari kategori sikap, komitmen dapat diartikan sebagai sikap karyawan dalam mengidentifikasikan dirinya terhadap organisasi kerja beserta rilai-nilai dan tujuannya, serta ingin tetap menjadi anggota untuk mencapai tujuan tersebut. Bila ditinjau dari kategori perilaku, maka komitmen merupakan ketergantungan karyawan terhadap aktivitasnya of masa lalu dalam perusahaan yang tidak dapat ditinggalkan karena alasan tertentu, misalnya ia akan kehilangan hal-hal yang telah diperolehnya selama ini dari perusahaan.

Penelitian tentang komitmen terhadap perusahaan yang akan dilakukan peneliti dibatasi pada pengertian komitmen sebagi suatu sikap, yaitu memandang komitmen sebagai sesuatu yang bersifat afektif emo- sional, artinya para karyawan tetap menjadi anggota dari perusahaan karena kemauannya sendiri, terlepas dari keuntungan-keuntungan ekonomis yang diperoleh.

Berdasarkan hasil beberapa penelitian tentang komitmen karyawan terhadap perusahaan, Steers dan Porter (1983) membagi faktor-faktor yang mempengaruhi komitmen terhadap perusahaan menjadi empat, yaitu (i) karakteristik personal, (ii) karaktersitik pekerjaan dan peranan, (iii) karaktersitik struktural, dan (iv) sifat dan kualitas pengalaman kerja. Faktor-faktor di atas merupakan faktor-faktor yang paling banyak diteliti, dan hasilnya menunjukkan bahwa faktor-faktor tersebut mendukung terbentuknya komitmen karyawan terhadap perusahaan. Hasil dari berbagai penelitian juga menunjukkan bahwa faktor-faktor tersebut mempunyai korelasi yang positif dengan komitmen karyawan terhadap perusahaan, kecuali tingkat pendid ikan, yang mempunyai korelasi yang negatif.

Selain keempat faktor tersebut, menurut Mathieu dan Zajac (1990), masih ada faktor lain yang mempengaruhi komitmen terhadap perusahaan, yaitu faktor hubungan dengan pemimpin/kelompok (group/ leader relationship) dan faktor karakter organisasi.

Berkaitan denḡan faktor hubungan dengan pemimpin/kelompok, Tosi dkk (1990) mengatakan bahwa hubungan antara seorang pemimpin dengan anak buahnya akan bervariasi, dan variasi hubungan tersebut akan tercermin melalui kualitas hubungan atasan-bawahan yang terjadi. Karena itu, kualitas hubungan atasan-bawahan berpengafuh terhadap terbentuknya komitmen seorang karyawan terhadap perusahaan.

Kualitas hubungan atasan-bawahan merupakan tingkatan yang menunjukkan sejauh mana kedekatan hubungan kerja dan sosial yang dijalin antara seorang 
atasan dengan seorang bawahannya dalam suatu dyad, sebagai hasil dari proses pembentukan peran yang dilakukan oleh seorang bawahan. Selanjutnya Landy (1989) menyatakan bahwa bila hubungan atasan-bawahan yang terjadi berkualitas tinggi, maka seorang atasan akan sering berdiskusi dengan bawahannya tentang masalah-masalah pribadi dan pekerjaan, dan atasan akan sangat tertarik pada kesulitan kerja yang dihadapi oleh bawahan. Hal ini menunjukkan adanya keterikatan personal dan sosial antara atasan dan bawahan. Keterikatan personal dan sosial yang terjadi ini akan menghindarkan bawahan dari rasa keterasingannya di perusahaan, dan selanjutnya meningkatkan komitmen karyawan. Sebaliknya pada kualitas hubungan atasan-bawahan yang rendah, semua hal tersebut tidak terjadi. Karena itu kualitas hubungan atasan-bawahan dianggap mempengaruhi komitmen karyawan terhadap perusahaan.

Selain faktorkualitas hubungan atasanbawahan, ada satu faktor lagi yang dianggap dapat mempengaruhi komitmen karyawan terhadap perusahaan, yaitu faktor persepsi terhadap pengembangan karir. Persepsi terhadap pengembangan karir $\mathrm{di}$ perusahaan menarik untuk dikaitkan dengan terbentuknya komitmen karyawan pada perusahaan, karena, menurut Slocum (1986) dewasa ini manusia bekerja tidak lagi sekadar untuk memenuhi kebutuhan fisiologis semata, tetapi juga membutuhkan suatu peningkatan non-materi yang lebih merupakan perwujudan aktualisasi diri, yaitu dalam bentuk perjalanan karir. Pengembangan Karir merupakan segala bentuk aktivitas dalam perusahaan yang dilaksanakan dalam rangka mempersiapkan individu untuk memperoleh kemajuan-kemajuan personal dalam melaksanakan rencana Karimya sehingga tujuan Karirnya dapat tercapai. Bagaimana karyawan mem- persepsikan pengembangan karir dapat mempengaruhi sikap dan perilaku kerjanya dalam perusahaan, karena persepsi individu terhadap suatu hal yang menjadi kebutuhannya merupakan salah satu faktor yang menentukan terbentuknya sikap dan perilaku.

Adanya pengaruh persepsi karyawan terhadap pengembangan karir atas komitmen karyawan secara implisit dapat dijelaskan dari eratnya hubungan antara persepsi terhadap pengembangan karir dengan salah satu faktor yang mempengaruhi terbentuknya komitmen karyawan, yaitu karakteristik pekerjaan. Mathieu dan Zajac (1990) mengatakan bahwa karakteristik pekerjaan yang mendukung berkembangnya variasi keahlian (skill variery), otonomi pelaksanaan tugas (task autonorny), adanya tantangan, dan bidang cakupan yang luas, akan mampu meningkatkan komitmen seseorang. Steers dan Porter (1983) menyebut hal ini sebagal pekerjaan yang kaya akan berbagai dimensi, yang dapat mendukung pengembangan diri, karirdan tanggungjawab seseorang, serta dapat meningKatkan Komitmen seseorang terhadap perusahaan. Karakteristik pekerjaan yang demikian ini akan mentmbulkan persepsi positif karyawan terhadap pengembangan karirnya. Hal ini terjadi dikarenakan berkembangnya variasi keahlian, otonomi pelaksanaan tugas, tantangan yang semakin besar, dan bidang cakupan yang semakin luas, merupakan karakteristik pekerjaan yang memungkinkan karir sesorang dapat berkembang. Bila karyawan tidak memperoleh karakteristik pekerjaan yang mendukung pengembangan diri, Karir, dan tanggungjawab, maka karyawan akan merasakan secara negatif pengembangan karirnya. Selanjutnya bagaimana persepsi karyawan terhadap pengembangan karirnya akan membawa konsekuensi pada sikap dan perilaku kerjanya. Salah satu d antara- 
nya yaitu komitmennya terhadap perusahaan.

Berdasar landasan teori d atas, hipotesis penelitian yang diajukan adalah:

1. Hipotesis mayor: Ada korelasi antara kualitas hubungan atasan-bawahan dan persepsi karyawan terhadap pengembangan karir dengan komitmennya pada perusahaan.

2. Hipotesis minor:

a. Ada korelasi positif antara kualitas hubungan atasan-bawahan dengan komitmen karyawan pada perusahaan.

b. Ada Korelasi positif antara persepsi karyawan terhadap pengembangan karir dengan komitmennya pada perusahaan.

Variabel-variabel yang terdapat dalam penefitian ini ialah: (i) Komitmen karyawan pada perusahaan, sebagai variabel tergantung, (ii) Kualitas hubungan atasan-bawahan, sehagai variabel bebas pertama, dan (iii) Persepsi karyawan terhadap pengembangan karir, sebagai variabel bebas kedua.

\section{METODE}

Subjek yang dipakai dalam penelitian ini ialah karyawan tetap tingkat staf pada PT Intan Pariwara, Klaten. Pengambilan subjek sebanyak 107 karyawan dilakukan secara acak dari populasinya yang bercini: sudah mempunyai masa kerja lebih setahun dan berpendidikan minimal SLTA.

Metode pengumpulan data yang dipakai adalah skala yang terdiri atas tiga buah, masing-masing untuk mengungkap variabel komitmen karyawan pada perusahaan, variabel kualitas hubungan atasanbawahan, dan variabel persepsi karyawan terhadap pengembangan karir. Skala komitmen karyawan pada perusahaan terdiri dari 57 aitem dengan koefisien validitas berkisar antara 0,238 sampai dengan 0,707 dan koefisien reliabilitasnya sebesar 0,949 . Skala kualitas hubungan atasan-bawahan terdiri dari 55 aitem dengan koefisien validitas berkisar antara 0,266 sampai dengan 0,736 dan koefisien reliabilitasnya sebesar 0,958 . Skala persepsi terhadap pengembangan karir terdiri dari 63 aitem dengan koelisien validitas berkisar antara 0,270 sampai dengan 0,873 dan koefisien reliahilitasnya sebesar 0,977.

Data yang diperoleh dianalisis dengan metode statistik. Teknik statistik yang dipakai ialah analisis regresi dua prediktor. Teknik ini dimaksudkan untuk menguji signifikansi hubungan antara kualitas hubungan atasan-bawahan dan persepsi terhadap pengembangan karir dengan komitmen karyawan pada perusahaan, dan untuk mengetahui seberapa besar sumbangan efektif kualitas hubungan atasan-bawahan dan persepsi karyawan atas po ngembangan karir terhadap komitmen karyawan pada perusahaan.

\section{HASIL}

Analisis data dengan menggunakan teknik analisis regresi dua prediktor memperoleh hasil sebagai berikut:

1. Besarnya koefisien korelasi ganda antara kualitas hubungan atasan-bawahan dan persepsi karyawan terhadap pengembangan karir dengan komitmen karyawan pada perusahaan (Ry.12) adalah sebesar 0,706 dan $F$ regresi sebesar 51,549 dengan $p<0,01$. Ini berarti bahwa terdapat korelasi yang sangat signifikan antara kualitas hubungan atasan-bawahan dan persepsi karyawan terhadap pengembangan karir dengan komitmen karyawan pada perusahaan. Sumbangan efektif kualitas hubungan atasan-bawahan terha- 
dap komitmen karyawan pada perusahaan sebesar 5,726 persen, sedangkan sumbangan efektif persepsi karyawan atas pengembangan karir terhadap komitmen karyawan pada perusahaan adalah sobesar 44,056 persen. Secara bersama-sama keefektifan variabel kualitas nubungan atasanbawahan dan variabel persepsi karyawan terhadap pengembangan karir dalam memprediksi tingkat komitmen karyawan pada perusahaan adalah sebesar 49,782 persen.

2. Koefisien korelasi antara kualitas hubungan atasan-bawahan dengan komitmen karyawan pada perusahaan (r1y) adalah sebesar 0,359 dengan $\mathrm{p}<0,01$. Ini berarti terdapat korelasi positif yang sangat signifikan antara kualitas hubungan atasan-bawahan dengan komitmen karyawan pada perusahaan.

3. Koefisien korelasi antara persepsi karyawan terhadap pengembangan karir dengan komitmen karyawan pada perusahaan ( $(2 y)$ adalah sebesar 0,689 dengan $p<0,01$. Ini berarti terdapat korelasi positif yang sangat signifikan antara variabel persepsi karyawan terhadap pengembangan karir dengan variabel komitmen karyawan pada perusahaan.

\section{DIS KUS}

Hasil penelitian ini adalah bahwa ada korelasi yang sangat signifikan antara variabel kualitas hubungan atasan-bawahan dan variabel persepsi karyawan terhadap pengembangan karir dengan komitmen karyawan pada perusahaan. Ini berarti bahwa seberapa tinggi kualitas hubungan antara karyawan dengan atasan, dan seberapa positif karyawan mempersepsikan karinya di perusahaan dapat berkembang. secara bersama-sama memberikan penga- ruh sebesar 49,782 persen bagi komitmen karyawan pada perusahaan. Adanya andil kedua variabel tersebut bagi terbentuknya komitmen karyawan pada perusahaan, seperti dikemukakan oleh Mathleu dan Zajac (1990), terjadi karena kedua variabel memang berhubungan secara erat dengan faktor-faktor yang mempengaruhi terbentuknya komitmen karyawan pada perusahaan.

Sumbangan efektif variabel kualitas hubungan atasan-bawahan terhadap komitmen karyawan pada perusahaan adalah sebesar 5,726 persen. Adanya korelasi posit if antara variabel kualitas hubungan atasan-bawahan dan komitmen karyawan pada perusahaan, menurut Landy (1989), terjadi karena kualitas hubungan atasanbawahan merupakan pencerminan tinggirendahnya keterikatan personal dan sosial antara seorang atasan dengan bawahannya. Adanya keterikatan personal dan sosial tersebut akan menghindarkan bawahan dari rasa keterasingan berada di perusahaan, sehingga hal ini akan membentuk dan meningkatkan komitmennya pada perusahaan. Hasil penelitian ini ternyata sejalan dengan hasil penelitian yang dilakukan oleh Kinicki dan Vecchio (1994) terhadap 138 loan officeryang menunjukkan bahwa kualitas hubungan atasan-bawahan berkorelasi positif dengan komitmen karyawan pada perusahaan. Ponelitian Major dkk (1995) terhadap 248 newcomers yang oflakukan secara jangka panjang (Jongitudinal) menemukan bahwa kualitas hubungan atasan-bawahan secara signifikan berkorelasi positif dengan komitmen karyawan dan kepuasan kerja, serta berkorelasi negatif dengan intensi keluar-masuk (turnover) karyawan.

Sumbangan efektif variabel persepsi terhadap pengembangan karir terhadap komitmen karyawan pada porusahaan adalah sebesar 44,056 persen. Peranan 
persepsi pengembangan karir terhadap komitmen karyawan pada perusahaan, menurut Slocum (1986), terjadi karena karyawansekarang ini mulai menekankan bahwa semua pekerjaan perlu dintegrasikan secara efektif dengan kebutuhan manusia, antara lain untuk pengembangan pribadinya. Oleh karena itu, karir menjadi hal yang paling berharga bagi seseorang dalam pekerjaannya. Slocum (1986) juga mengemukakan bahwa dewasa ini manusia bekerja tidak lagi sekadar untuk memenuhi kebutuhan fisiologis saja, tetapi membutuhkan suatu peningkatan non-materi yang lebih bersifat aktualisasi diri dalam bentuk pengembangan karir. Dalam rangka untuk memenuhi kebutuhan karirnya, individu melakukan persepsi terhadap kemungkinan pengembangan karirnya di perusahaan tempat i bekerja. Bila la mempersepsikan bahwa pengembangan karirnya di perusahaan dapat memenuhi kebutuhan karirnya, maka akan terbentuk persepsi yang positif terhadap pengembangan karirnya. Sebaliknya, apabila individu mempersepsikan bahwa pengembangan karirnya di perusahaan tidak dapat memenuhi kebutuhan karirnya, maka akan terbentuk persepsi negatif terhadap pengembangan karir. Positif atau negatif persepsi karyawan terhadap pengembangan karirnya akan membawa konsekuensi yang berbeda bagi kepuasan kerja karyawan. Karyawan yang mempersepsikan pengembangan karimya secara positif akan mendapatkan kepuasan kerja, sehingga akan menghindari sikap dan perilaku yang menghambat pencapaian tujuan perusahaan; yang berarti ia memiliki komitmen pada perusahaan. Se baliknya, bila karyawan mempersepsikan secara negatif pengembangan karinya di perusahaan, maka ia akan memiliki kepuasan kerja yang rendah. Akibatnya, menurut Ma:hieu dan Zajac (1990), kepuasan kerja yang rendah menyebabkan komitmen karyawan pada perusahaan juga menjadi rendah.

\section{KESIMPULAN}

Penelitian ini menyimpulkan bahwa baik secara sendiri-sendiri maupun secara bersama-sama variabel kualitas hubungan atasan-bawahan dan variabel persepsi karyawan terhadap pengembangan karir mempunyai peran terhadap besar-kecilnya komitmen karyawan pada perusahaan. Variabel persepsi terhadap pengembangan karir memberikan sumbangan efektif yang lebih besar daripada variabel kualitas hubungan atasan bawahan terhadap komitmen karyawan pada perusahaan. Oleh sebab itu, perusahaan, dalam hal ini PT Intan Pariwara, Klaten, secara relatif agar lebih memperhatikan lagi program pengembangan karir bagi karyawannya, tanpa mengabaikan kualitas hubungan atasanbawahan, dan variabel-variabel lain d luar kedua variabel penelitian, yang secara teoritis juga kut berpengaruh terhadaptingkat komitmen karyawan.

Hasil penelitian ini sejalan dan mendukung hasil penelitian yang dilakukan oleh Kinicki dan Vecchio (1994) terhadap 138 karyawan loan officerdan penelitian longitudinal yang dilakukan Major dkk (1995) terhadap 248 newcomers. Hasil penelitian ini juga menunjukkan bahwa karyawan tidak hanya bekerja untuk dapat memenutri kebutuhan dasa īña, tetapi juga untuk memenuhi kebutuhan yang tingkatannya lebih tinggi, yaitu aktualisasi diri. Oleh sebab itu hasil penelitian ini secara implisit mempertegas pernyataan bahwa dalam melakukan aktivitas, seseorang tidak hamya berusaha untuk satu kebutuhan saja akan tetapi dapat juga untuk memenuhi beberapa kebutuhan sekaligus. 


\section{DAFTAR PUSTAKA}

Bernas. 1996. BPS Bajak 15 Bankir Citibank. Bernas, 12 Mei 1996. Yogyakarta.

Kinicki, A.J. dan Vecchio, R.P. 1994. Influences on the Quality of SupervisorSubordinate Relations: The Role of Time Pressure, Orgabizational Commitment, and Locus of Control. Journal of Organizational Behavior, 15, 7582.

Kompas. 1995. Kartika Plaza Lumpuh Akibat Pekerja Mogok. Kompas, 3 Oktober 1995. Jakarta.

Kompas. 1996. THR Kurang, Pēkerja Pabrik Rusak Kantor. Kompas, 13 Februari 1996. Jakarta.

Landy, F.J. 1989. Psychology of Work Behavior, California: Brooks/Cole Publishing Company.

Major, D.A., Kozlowski, S.W. and Chao, G.T. 1955. A Longitudinal Investigations of Newcomers Expectations, Early Socialization Outcomes, and the Moderating Effects of Role Develop- ment Factors. Journal of Applied Psychology, 8C, 416-431.

Mathieu, J.E. and Zajac, D.M. 1990. A Review and Meta Analysis of the Antecedents, Correlates, and Consequences of Organizational Commitment. Psychological Bulletin. 108, 171-194.

Nasution, A. 1994. APEC: Tantangan dan Dampaknya pada Ekonomi Indonesia. Bank \& Management. September. Oktober 1994, 24, 3-15.

Preffer, ل. 1996. Keunggulan Bersaing Molalui Manusia (Terjemahan). Jakarta: Binarupa Aksara.

Slocum, HW. 1986. Organizational Behavior. St Paul: West Publisher Co.

Steers, R.M. and Porter, L.W. 1983. Marivation and Work Behavior. USA: McGrawHill Book Co.

Tosi, H.L., Rizzo, J.R., and Carroll, S.J. 1990. Managing Organizational Behavior. 2nd edition. New York: Harper Collins Publishers.

\section{娄 米}

